\title{
Board Characteristics and Asymmetric Cost Behavior: Evidence from Egypt
}

\begin{abstract}
Purpose- This study aims to provide further evidence on asymmetric cost behavior (cost stickiness) from one of the emerging economies, Egypt. The study provides also empirical evidence on the potential impact of corporate governance on nature and extent of asymmetric cost behavior.
\end{abstract}

Design/methodology/approach-The study estimates three multiple regression models using Ordinary Least Squares (OLS) to examine the behavior of Cost of Goods Sold (COGS) and the influence of board characteristics and other control variables in a sample of 80 listed companies during 2008-2013.

Findings-The analysis provides evidence on COGS asymmetric behavior, where the analysis finds that COGS increase by $1.05 \%$, but decrease by $0.85 \%$ for an equivalent activity change of $1 \%$, which contradicts the traditional cost model assumption that costs behave linearly. In addition, the analysis finds that firm-year observations with larger boards, role duality, and higher non-executives ratio exhibit greater cost asymmetry than others do while firms-years with successive sales decrease, higher economic growth and institutional ownership found to exhibit lower cost stickiness.

Originality/value-This study contributes by providing evidence on asymmetric cost behavior from one of emerging economies. Further, the study extends the very few studies on the relationship between corporate governance and asymmetric cost behavior. In addition, the study contributes by examining a different cost type (COGS) that found to be examined by very few studies. Finally, the study provides an evaluation of the 2007 Egyptian Corporate Governance Code, from the cost behavior context.

Keywords: Corporate Governance, Cost Asymmetry, Cost Stickiness, Egypt 


\section{Introduction}

Understanding how costs behave is a vital and critical issue for managers, management accountants, and financial analysts. Several techniques, such as Cost-Volume-Profit (CVP) analysis, pricing methods, and Activity-Based Costing (ABC), need to analyze the cost behavior. Almost all these techniques, among others, depend on the traditional cost model.

The traditional cost model $(y=a+b x)$ assumes that costs respond proportionately to activity/volume changes. The costs are assumed to respond symmetrically (equally) to an equivalent activity/volume change. If volume $(\mathrm{x})$ changes by $1 \%$, total costs $(\mathrm{y})$ will increase or decrease by a symmetric (equal) ratio, since the slope of the model (b) is fixed and total fixed costs (a) are fixed too, within the relevant range.

Nevertheless, the literature provides both old and recent empirical evidence on asymmetric cost response to equivalent activity changes. According to Guenther et al. (2014), Brasch (1927) is the first that finds the cost curve when the activity increases differs from the cost curve when the activity decreases, which results in an asymmetric cost function. Recent evidence is provided by Anderson et al. (2003), who find that SG\&A costs of a USA sample increase by $0.55 \%$ per a $1 \%$ increase in demand, but decrease by only $0.35 \%$ per a $1 \%$ decrease in demand. They label the costs that behave this way as "sticky cost" or "cost stickiness." Further, Porporato and Werbin (2012) find that when demand increases (decreases) by a $1 \%$, total costs increase (decrease) by $0.60 \%(0.38 \%)$, $0.82 \%(0.48 \%)$, and $0.94 \%$ (0.55\%), for Argentina, Brazil, and Canada banking samples, respectively. This means that costs increase higher than their decrease per a $1 \%$ demand change, indicating that costs behave asymmetrically, not symmetrically, as assumed by the tradition cost model.

The normal cost behavior occurs when managers respond equally to the same demand changes. When the demand increases, managers should adjust the resources upward by employing new resources to accommodate the increased demand, and thus, costs will increase. On the other hand, when the demand decreases, managers should adjust the resources downward by retiring the slack resources, and thus, costs will decrease. Accordingly, when the demand increase equals the demand decrease, the cost response should be symmetric. However, the literature finds that managers' response to the same demand change differs, and thus, cost response differs, which contradicts the traditional cost model.

The literature explains some reasons of asymmetric cost behavior. First, Anderson et al. (2003) explain that when activity decreases, managers choose between two types of costs: holding costs if decide to operate with slack resources and adjustment costs if decide to retire the slack resources. Managers will trade-off between the two costs and will be more likely to choose the decision that yields the lower costs. If managers find that costs needed to adjust the resources will be higher than costs incur if decide to operate with slack resources, they will decide not to adjust the resources when the activity declines, causing cost stickiness. Second, Anderson et al. (2003) explain that if managers are optimistic about the demand or feel that demand decline is temporary and that the demand will recover soon, they will choose to operate with slack resources and will not adjust the resources when the activity declines, causing higher cost stickiness.

Another set of studies attributes the asymmetric cost behavior to the opportunistic managers' intervention. For example, Chen et al. (2012) argue that "Empire-Building" incentives induce managers to grow the firm beyond its optimal size. They argue that 
when the demand increases, empire-building managers increase SG\&A costs too rapidly, but decrease SG\&A costs too slowly when demand declines, in order to increase the firm size, which results in "sticky cost." Further, Dierynck et al. (2012) find that managers under pressure to meet or beat earnings benchmarks, increase labor costs to a smaller extent when demand increases, but decreases labor costs to a larger extent when demand declines, in order to save costs, which leads costs to behave as "anti- sticky." Moreover, Kama and Weiss (2013) suggest that researchers should exert efforts to understand and investigate determinants of cost behavior in light of the managers' motivations, especially the agency-driven incentives that affect the resources adjustment decisions.

Given that the asymmetric cost behavior results mainly from managers' deliberate and opportunistic intervention when demand changes, there is a need to mitigate this intervention, and thus, bring the cost response closer to the optimal cost response level. Corporate Governance (CG) may be a useful suggestion. An effective CG system is thought to influence positively the managers' decisions and mitigate managerial opportunism (Jensen and Meckling, 1976; Jensen, 1993; Shleifer and Vishny 1997; Chen et al. 2012). Board of directors and audit committees are $C G$ mechanisms that are responsible for controlling and monitoring the managers' decisions on behalf of shareholders. Accordingly, they, as CG mechanisms, could influence positively the managers' decisions regarding cost behavior. Chen et al. (2012) assume that strong CG may bring cost stickiness levels closer to the optimal cost response level. Further, Chen et al. (2012) and Pichetkun (2012) find that the asymmetric cost behavior extent is less intense in the strong CG sub-sample than in the weak CG sub-sample, which implies that the CG system could mitigate cost stickiness.

Accordingly, this study aims to achieve two main objectives. The first is to examine whether costs behave asymmetrically in emerging economies, compared to results found in several developed countries. The second is to examine whether and how board structure as a governance mechanism could affect cost behavior.

The study contributes in the following ways. First, the study enriches the literature by investigating one of the possible solutions for cost stickiness by extending the extant work of Chen et al. (2012) who examine how CG could affect stickiness of SG\&A in the US. This study supports the hypothesis of Chen et al. (2012) that effective CG could mitigate cost stickiness. The study of Chen et al. (2012) is one of very limited studies that suggest a solution for cost stickiness, where the majority found to diagnose the stickiness as a problem. However, there is still a need for more empirical evidence on the effectiveness of $\mathrm{CG}$ as a suggested mechanism for mitigating cost stickiness through affecting and monitoring the managers' decisions. The results of Chen et al. (2012) on the influence of CG on cost stickiness are restricted to the USA and to SG\&A costs only. However, this study contributes by investigating this influence in one of emerging economies and by investigating a different cost type (COGS). Second, the study is one of the early and the few studies that examine asymmetric cost behavior in Egypt and the Arab World. Third, this study evaluates the 2007 Egyptian CG Code but from a different context, the cost stickiness context.

The remainder of my paper is organized in the following sections. The second section exhibits a theoretical framework that summarizes the CG reforms in Egypt, reviews a set of the most relevant studies classified into three groups and discusses three hypotheses. The third section exhibits the methodology. The fourth section presents and discusses the results while the last section concludes. 


\section{Theoretical Framework \& Hypotheses Development}

This study depends on two important literature arguments. The first is that asymmetric cost behavior results mainly from the managers' deliberate decisions (Anderson et al. 2003) and the opportunistic intervention (Chen et al. 2012) in the process of resources adjustment when the activity changes, and that the managerial decisions taken to adjust the resources are main drivers of cost behavior (Baumgarten, 2012). The second is that CG could bring the cost response level closer to the optimal cost response level (Chen et al. 2012) and that the CG different mechanisms could affect several managerial decisions including those of resources adjustments. Accordingly, this section exhibits CG reforms in Egypt, provides a review of the literature classified into three groups, then formulates the study hypotheses by discussing how three of the board characteristics could affect the asymmetric cost behavior.

\subsection{Corporate Governance Reforms in Egypt}

Egypt has witnessed essential CG reforms during the last two decades, which have affected significantly the number of listed companies on the Egyptian Stock Exchange (EGX). Shehata \& Dahawy (2013) state that applying the governance rules contributes to decreasing the number of companies included in the stock market from 1148 companies at the beginning of 2002 to 333 by mid-2009, to 240 in April 2012.

In June 2002, the Egyptian Capital Market Authority (CMA) issued the resolution No. 30 , regarding rules of listing and delisting of companies on the EGX, as a first step for setting and developing CG rules. Next, In October 2005, the Ministry of Investment issued the first Egyptian Corporate Governance Code (ECGC) for corporations. The rules of ECGC comply with the principles of CG issued by the OECD.

Next, in November 2006, the CMA announced the project of executive rules of $C G$, which are derived from the 2005 ECGC. Moreover, the CMA considered applying these rules one of the main requirements to stay listed on the Stock Exchange, in an attempt to convert applying of CG rules from voluntary to mandatory. The CMA intended to make applying of CG executive rules mandatory, starting from January 1, 2007, concurrently with applying the new version of Egyptian Accounting Standards. However, many companies were not ready, so the CMA allowed them a period to correct their position to comply with these rules. On March 11, 2007, CMA issued formally resolution No. 11 of 2007, on the executive rules of CG that must apply on all listed companies; otherwise, these companies will be delisted.

\subsection{Literature Review}

This section presents three groups of the most relevant studies. The first group presents some studies that mainly provide evidence on asymmetric cost behavior.

First, Anderson et al. (2003) provide a pioneer model to discover whether costs behave asymmetrically, where the majority of cost stickiness studies follow their model. The authors apply this model using a sample of USA firms during 1979-1998 and find that SG\&A increase by $0.55 \%$, but decrease by $0.35 \%$ when activity changes by $1 \%$. Results indicate also that during economic prosperity periods, cost stickiness is greater than during recession periods and that extent of cost stickiness is greater in firms with higher assets and employees intensity. One more study in USA, Subramaniam and Weidenmier (2003), 
examines a sample of 9,592 US-listed companies and find that both SG\&A and COGS exhibit asymmetric cost behavior, especially when activity change by more than 10 percent.

Further, Porporato \& Werbin (2012) examine 270 observations for Argentina, 192 for Brazil, and 55 for Canada, during 2004-2009. They find that total costs increase by $0.60 \%, 0.82 \%$, and $0.94 \%$ in banks samples of Argentina, Brazil, and Canada, but decrease by $0.38 \%, 0.48$, and $0.55 \%$ per $1 \%$ sales change, which asserts cost stickiness in the three samples, but with different degrees. One recent study, Abu-Serdaneh (2014), examines all manufacturing companies listed in Jordan during 2008-2012. The author finds that SG\&A costs are symmetric, neither sticky nor anti-sticky. The study finds that COGS behaves as anti-sticky. Further, companies with higher assets intensity show higher COGS stickiness. SG\&A found to show higher stickiness for - free cash flow and a less stickiness for debt intensity. Moreover, Banker and Byzalov (2014) provide an international study through examining a total sample of 315,967 firm-years in 20 countries during 1988-2008. Authors provide comprehensive evidence that asymmetric cost behavior is a pervasive global phenomenon, where operating costs were found to be sticky for 16 countries out of 20. One more study, Via and Perego (2014), examines cost behavior in samples of Italian listed and nonlisted small and medium-sized firms during 1999-2008. They detect cost stickiness for only total labor costs, but not for SG\&A, COGS, or operating costs. However, the stickiness of operating costs is detected in the sample of listed firms only. Authors conclude that the results of investigating small and medium-sized firms are not consistent with prior studies.

One recent study conducted by the author of this study, Ibrahim (2015), examines how SG\&A, COGS, and operating costs behave in Egyptian business environment during 2004-2011, and how economic growth affects cost behavior. The results indicate that both SG\&A and COGS behave sticky while operating costs behave anti-sticky. Besides, SG\&A found to be sticky during the prosperity period before the 2008 financial crisis, but antisticky during the recession period after the 2008 financial crisis, while COGS found to be sticky in both periods, but its stickiness extent was larger in the prosperity period. The author concludes that economic growth could affect the cost behavior nature and extent.

The second group presents three studies that investigate the relationship between managerial incentives, earnings management, and asymmetric cost behavior. The first study, Dierynck et al. (2012), investigates 51,826 firm-year observations in Belgian, during 1993-2006. The authors find that managers meeting or beating the zero earnings benchmark increase labor costs to a smaller extent when activity increases, but decrease labor costs to a larger extent when activity decreases, which makes labor costs take a more symmetric cost behavior form. However, managers who do not face significant earnings benchmark pressure were found to limit the employee dismissals, which make labor costs take a more asymmetric cost behavior form. The second study, Kama and Weiss (2013), examines 11,758 US-listed companies, during 1979-2006. Authors find that when managers face incentives to avoid losses or earnings decreases, or to meet financial analysts' forecasts, they accelerate downward adjustment of slack resources for sales decrease, which mitigates the magnitude of cost stickiness. The third study, Koo et al. (2015), investigates the relationship between earnings management and cost stickiness in a sample of USA firms during the years 1997-2007. They find that when activity declines, managers cut down costs aggressively to manage earnings, which mitigates cost stickiness while firms with fewer earnings management incentives found to show greater cost stickiness. 
The third group exhibits five studies that examine the relationship between CG and asymmetric cost behavior. First, Calleja et al. (2006), examines 13,662 US firm-years, 8,659 UK firm-years, 1,694 German firm-years, and 2,968 French firm-years during 19882004. Results indicate that operating costs behave asymmetrically in all examined countries, but the extent of stickiness in France and Germany is greater than in the UK and USA. Authors ascribe this difference to the different laws applied in those countries, where both the UK and the USA are operating under the common laws while France and Germany are operating under the code laws. Second, Chen et al. (2012) assume that CG is a potential solution that could bring the cost behavior closer to the optimal cost level and examine a sample of USA firms during 1996-2005. They find that SG\&S behave sticky and that cost stickiness is less intense in a strong CG sample, but more intense in a weak CG sample, concluding that CG could mitigate cost stickiness. Results indicate also that board independence, institutional ownership, and takeover threats could mitigate the influence of agency problem on cost stickiness.

Third, Pichetkun (2012) assumes that CG could affect cost stickiness and investigates a sample of firms listed in Thailand in 2001-2009. Results indicate that firm-year observations with weak CG exhibit greater cost stickiness compared with a sub-sample of stronger CG. However, the study does not examine the influence of any of board characteristics on cost stickiness. Fourth, Banker et al. (2013), investigates a total sample of 128,333 observations for 15,833 companies located in 19 OECD countries, during 1990-2008. Authors find that the level of strictness of the country-level employment protection legislation affects the extent of cost asymmetric behavior. They conclude that the stricter employment protection legislations restrict the ability of managers to cut slack labor resources when the demand declines, which increases cost stickiness. Finally, one recent study, Xue and Hong (2015), investigates cost behavior and the potential influence of CG in a sample of 7,702 firm-year observations of firms listed in China during 20032010. They find that earnings management non-suspected firms show a higher level of cost stickiness, that effective CG could mitigate the extent of cost stickiness and that the interaction effect between $\mathrm{CG}$ and earnings management alleviates cost stickiness.

The review of the literature concludes the following gaps. Firstly, I find the majority of studies are conducted in developed countries (e.g., USA, UK, Germany, Canada, and France). Further, only two studies, Abu-Serdaneh (2014) and Ibrahim (2015) are conducted on the Middle East and the Arab Region. Secondly, I notice that few studies examined COGS, compared with SG\&A. Thirdly, I notice paucity in studies that examine the relationship between different CG mechanisms and asymmetric cost behavior, especially boards' characteristics. Accordingly, this study contributes by providing evidence on asymmetric cost behavior, but from different contexts, the Egyptian and emerging economies contexts. Further, the study extends the extant few studies on the relationship between CG and asymmetric cost behavior. In addition, the study contributes by examining COGS that is examined by a few studies. Further, the study provides an evaluation of the ECGC after its formal applying in 2007.

\subsection{Hypotheses Development}

This study examines how one of main CG mechanisms could influence asymmetric cost behavior. The study suggests that board of directors could affect managers' decisions through controlling and monitoring functions, and thus could affect cost behavior, since managers have to make adjustment decisions when activity changes, which will affect cost 
behavior. Baumgarten (2012) asserts that managerial decisions regarding the resources adjustments when activity changes are main determinants of cost behavior. Therefore, any mechanism that could affect managers' decisions could affect also cost behavior. Accordingly, this study examines how three boards' characteristics could affect asymmetric cost behavior: board size, role duality, and non-executive directors.

\section{Board Size}

The literature presents a debate on whether large boards are better than small boards. A set of studies thinks that larger boards are more able to monitor, control, and provide companies with diversity that could mitigate dominance of $\mathrm{CEO}$ and increase experience (e.g. Goodstein et al. 1994; Mak and Roush, 2000). However, others favor smaller boards. For example, Jensen (1993) argues that larger boards may suffer from more difficulty in coordination among board members. Further, Goodstein et al. (1994) argue that members of the larger boards are less likely to become involved in strategic decisions. Large boards may also impede communication and information processing (Jensen 1993; Yermack 1996; Huther 1997; John and Senbet, 1998).

This study favors smaller boards, since I argue that several decisions' conflicts may arise because of a large number of members on boards, which may decrease the CG quality and create opportunities, such as managers' intervention in cost behavior. Empirically, some studies indicate that small boards are preferable (e.g., Yermack 1996; Fuerst and Kang, 2004; Bozec 2005; Haniffa and Hudaib, 2006; Cornett et al. 2007). Therefore, the study first hypothesis is:

\section{$H_{1}$ : Firm-year observations with larger boards exhibit greater cost stickiness}

\section{Role Duality}

Role duality occurs when board Chairman and CEO are the same person. Board Chairman/CEO separation is a CG mechanism that increases board independence. Agency theory advocates separation of the two roles to maintain essential checks and balances against management (Haniffa and Cooke 2002). Moreover, Gul \& Leung (2004), AbdelFattah (2008) and Chen et al. (2012) believe that role duality bans board independence and reduces CG quality through concentration of decision-making power. Empirically, several studies show that role duality is not an aspect of effective governance (e.g., Vafeas and Theodorou, 1998; Laing and Weir, 1999; Heracleous, 2001; Kelton and Yang, 2008). According to the Egyptian CG code, boards should appoint a chairman who is not also CEO.

Consistent with the extant literature, I argue that board Chairman/CEO separation is an indicator of an effective $\mathrm{CG}$ system, which creates opportunities for better alignment with interests of shareholders. Further, role duality may lead to opportunistic intervention in several decisions including those of resources adjustments, which also affect the cost behavior. Therefore, the study second hypothesis is:

\section{H2: Firm-year observations with role duality exhibit greater cost stickiness}




\section{Non-executives}

Boards consist of both insiders (executives) and outsides (non-executives). It is believed that the higher the ratio of outside directors on boards, the higher the board independence. Agency theory asserts that boards should include many non-executive directors, allowing them to monitor and control executives and protect interests of shareholders. Moreover, Fama \& Jensen (1983) argue that independent directors on boards could mitigate managers' opportunistic actions through effective monitoring. Forker (1992) documents that a higher ratio of non-executives on boards makes them more responsive to shareholders' interests and investors. Empirically, many studies indicate that a large proportion of non-executives is a sign of good governance (Helland and Sykuta, 2005; Haniffa and Hudaib, 2006; Cornettet al. 2007; Kelton and Yang, 2008). Consequently, including many non-executive directors on boards may be important for effective CG.

Accordingly, I believe that segregation of duties and independence are critical board characteristics that can increase the CG quality as whole, and this separation can influence positively the managers' decisions including the costs' adjustment decisions, and thus cost behavior. Therefore, the study third hypothesis is:

\section{H3: Firm-year observations with higher executives' ratio exhibit greater cost stickiness}

\section{Methodology}

\subsection{Sample and Data}

Table 1 exhibits two main samples, the basic sample is to analyze COGS behavior, and the CG sample is to investigate the influence of board characteristics on asymmetric cost behavior. The companies listed on the Egyptian Stock Exchange during 2008-2013 represent the study population while the 100 listed companies that make up EGX100 index represent the study initial samples. The final sample comprises 80 non-financial listed companies after excluding banks and other financial institutions due to their special standards and regulations. Moreover, I depend on annual reports issued by companies and disclosure books issued regularly and formally by EGX to extract any required data on models' variables. I extract data on costs and sales variables directly from income statements embedded in the annual reports, which are available on the companies' websites. Further, I extract data on corporate governance variables from disclosure books, where the first page of each company in the disclosure book includes data on board members, their names and positions in addition to data on executives and ownerships structure. Table (2) shows source of data for each variable.

\section{Insert Table 1 about here}

As shown in the table (1), I apply some data screening criteria following Anderson et al. (2003), Chen et al. (2012) and Dierynck et al. (2012). First, I exclude firm-year observations of financial companies. Second, I discard any firm-year observation with missing data on costs or net sales. Third, I exclude any firm-year observation with costs exceeding net sales for the current year. Finally, I consider any firm-year observation with a standardized residual of more than the absolute value of three an extreme observation (outlier) that should be excluded. 


\title{
3.2 Models
}

To test the study hypotheses, three models are applied. Model (1) is to examine the stickiness of COGS; Anderson et al. (2003) and Chen et al. (2012) apply this model to examine the stickiness of SG\&A costs in USA samples. Then, Model (1) is extended by adding 3 corporate governance variables as interaction-terms, then added as a standalone variable, as shown in Model (2). Model (3) is the same as model (2), but it includes 3 control variables. Year dummies are included in all regression models.

Anderson et al. (2003) provide a pioneer regression model to discover whether the costs increase is different from the costs decrease for an equivalent activity change. This model is able to measure the costs' response to contemporaneous changes in sales and is able to discriminate between periods of sales increase and decrease (Anderson et al. 2003). The model contains a dummy variable (DecDummy) that is able to distinguish between revenue-decreasing and revenue-increasing years. Therefore, the majority of studies followed Anderson et al. (2003) and applied their model (e.g. Calleja et al. 2006; Kama and Weiss, 2013; Ibrahim, 2015). To examine the potential correlation between board characteristics and cost asymmetry, I extend the basic model by including board size, role duality, and non-executives' ratio and other control variables by multiplying each variable by DecDummy ${ }_{i t} \times \log \left(\Delta\right.$ Sales $\left._{i t}\right)$, which creates three-way interaction terms, following the relevant studies such as Anderson et al. (2003), Chen et al. (2012), Dierynck et al. (2012) and Ibrahim (2015).

Nevertheless, this inclusion could increase the Multicollinearity level between the model continuous variables. To avoid this problem, I follow Chen et al. (2012) and undertake mean-centering for all continuous variables included in the interaction terms (except for role duality as a dummy variable). Mean-centering is a statistical procedure that subtracts the variable values from the variable mean. Aiken and West (1991) and Chen et al. (2012) argue that mean-centering could reduce Multicollinearity and ease interpretation of the main effects. Moreover, the models apply the ratio form and log specification, since Anderson et al. (2003) suggest that these forms could alleviate the potential heteroskedasticity and enhance comparability of variables across companies.

\section{Basic Model (1):}

$\log \left(\Delta \operatorname{COGS}_{\mathrm{it}}\right)=\beta 0+\beta 1 \log \left(\Delta \operatorname{Sales}_{\mathrm{it}}\right)+\beta 2 \operatorname{DecDummy}_{\mathrm{it}} * \log \left(\Delta \mathrm{Sales}_{\mathrm{it}}\right)+\Sigma$

\section{Model 2: (No controls)}

\author{
$\log \left(\Delta \mathrm{COGS}_{i t}\right)=\beta 0+\beta 1 \log \left(\Delta \operatorname{Sales}_{\mathrm{it}}\right)$ \\ $+\beta 2$ DecDummy $_{i t} \times \log \left(\Delta\right.$ Sales $\left._{i t}\right)$ \\ $+\beta 3$ DecDummy $_{i t} \times \log \left(\Delta\right.$ Sales $\left._{\mathrm{it}}\right) \times$ Board Size $_{i t}$ \\ $+\beta 4$ DecDummy $_{i t} \times \log \left(\Delta\right.$ Sales $\left._{\mathrm{it}}\right) \times$ Role Duality $_{i t}$ \\ $+\beta 5$ DecDummy $_{\mathrm{it}} \times \log \left(\Delta\right.$ Sales $\left._{\mathrm{it}}\right) \times$ Non-Executives $i t$ \\ $+\beta 6$ Board Size $_{i t}+\beta 7$ Role Duality $_{i t}+\beta 8$ Non-Executives $_{i t}+\Sigma$
}




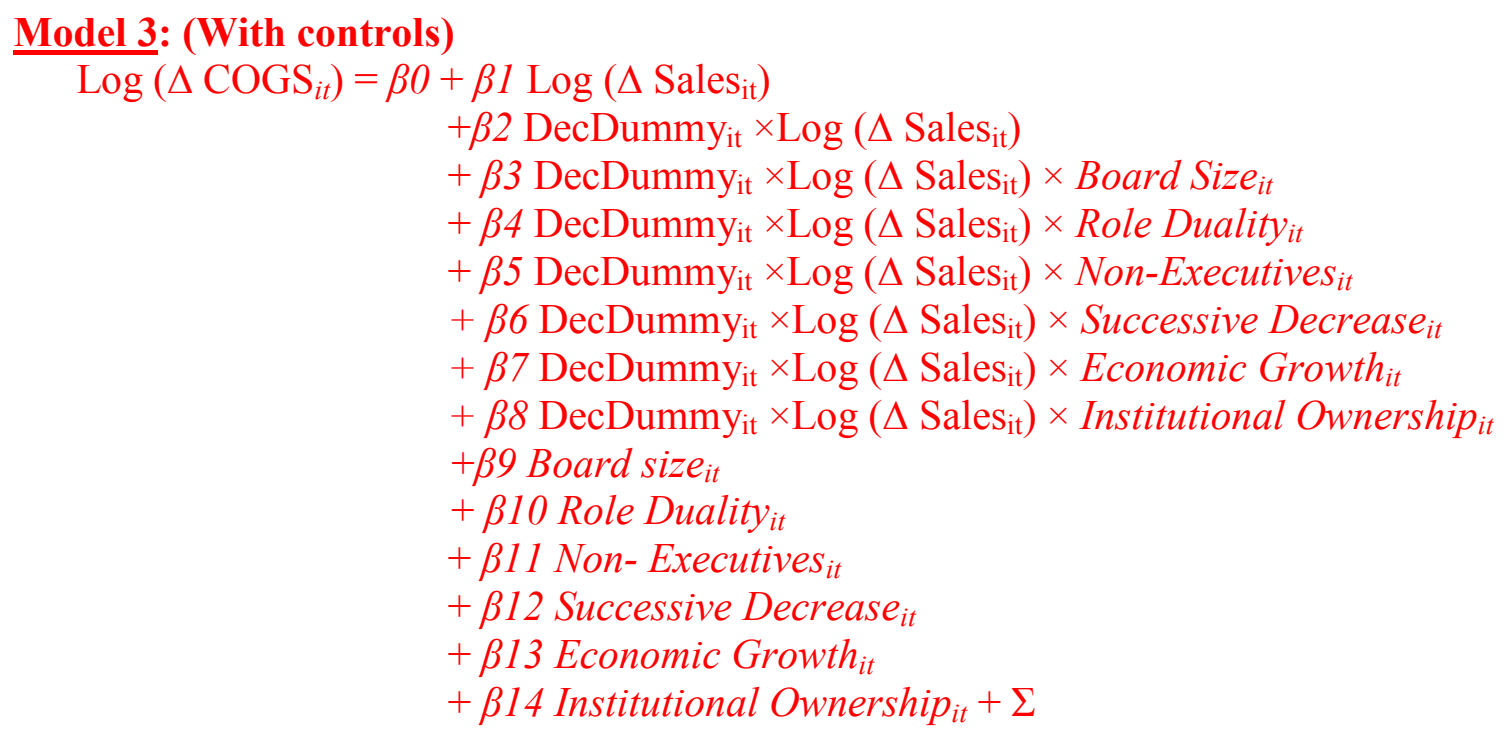

\subsection{Control Variables}

Model (3) includes 3 control variables: successive decrease, economic growth and institutional ownership. The first control successive decrease is to test the hypothesis that managers become more certain that demand decline is permanent not temporary when demand declines for 2 successive periods, and thus, managers start to retire slack resources, which decreases stickiness. A positive significant coefficient implies that cost stickiness degree is lower during a demand-declining period preceded by demanddeclining periods. The second control economic growth is measured by real GDP and is used to test the hypothesis that if demand declines during economic growth periods, managers are less likely to retire slack resources, since managers consider this decline temporary than if this decline happened during lower economic growth periods (Anderson et al. 2003; Banker et al. 2013; Ibrahim, 2015), and thus, cost stickiness is likely to be higher during the economic growth periods, since managers will not retire slack resources. Finally, institutional ownership is included as a control variable in order to test the hypothesis that institutional ownership provides better monitoring. Agency theory and efficient-monitoring hypothesis suggest that institutional investors are sophisticated investors who hold experience and power than individuals, and thus, could monitor effectively the managerial behavior (Jensen and Meckling, 1976; Abdel-Fattah, 2008). Chen et al. (2012) find that governance mechanisms such as institutional ownership and board independence are effective in mitigating the impact of agency problem on stickiness of SG\&A costs. The definitions and measurements of all the models' variables are exhibited in Table (2).

\section{Insert Table 2 about here}

\section{Data Analysis \& Results}

In this section, I provide and discuss three analyses: descriptive analysis, basic regression analysis, and robust regression analysis. To prove cost stickiness, both $\beta 1$ and $\beta 2$ should be statistically significant, and $\beta 1$ should be positive and $\beta 2$ should be negative. To explain the results of board characteristics and control variables included in Models (2) 
and (3), I follow a rule set by Anderson et al. (2003), whereby the stickiness degree increases (decreases) with the magnitude of the negative (positive) coefficients $\beta 2$ through $\beta \mathrm{m}$.

\subsection{Descriptive Statistics}

Panel (A) of Table 3 exhibits that COGS average is 943 million Egyptian Pounds, with a median of 170 million, which are lower than COGS mean of $\$ 885.48$ million and a median of $\$ 73.64$ of the USA sample as reported by Subramaniam \& Weidenmier (2003) by considering the exchange rates. The net sales mean of the study sample is 1,312 million Egyptian Pounds, with a median of 282 million, which are lower than net sales mean of $\$ 5,383$ million and a median of $\$ 1,433$ million for the USA sample examined by Chen et al. (2012), and lower than net sales means of $\$ 1,277, \$ 1,153$, and $\$ 1,294$ million for the USA samples examined by Anderson et al. (2003), Calleja et al. (2006), and Subramaniam \& Weidenmier (2003), respectively. The COGS mean as a percentage of net sales is $72 \%$, which is higher than mean of $63.77 \%$, found by Subramaniam and Weidenmier (2003) in a USA sample and $64.51 \%$ reported by Ibrahim (2015) for an Egyptian sample.

\section{Insert Table 3 about here}

Panel (B) of Table (3) shows the descriptive statistics on the corporate governance variables. The board size mean is 7.51 and the median value is 7 members. The mean and median are lower than 9.15 and 9 found by Chen et al. (2012) in a USA sample. For role duality, table 2 shows a mean of 0.65 implying that $65 \%$ of the study sample boards' chairmen are working as CEOs at the same time, which is slightly higher to $63 \%$ found by Chen et al. (2012) in a USA sample. For a ratio of independent directors on boards to total boards members, table 2 exhibits a ratio of $69 \%$, which is slightly higher than $66 \%$ found by Chen et el. (2012).

Panel (C) of Table (3) provides descriptive statistics on control variables. The mean value of Successive Decrease is 0.40 indicating that $40 \%$ of firm-years experiencing two successive sales declines during the last two year, which is higher than 0.23 reported by Chen et al. (2012). While the median is 0 similar to Chen et al. (2012), implying that the median firm did not experience any sales declines during the last two years. The mean value of Economic Growth is 3.16, indicating that the average economic growth \% during the study period is $3.16 \%$. Finally, the mean value of Institutional Ownership is $20 \%$ indicating that $20 \%$ on average of the sample firms' ownership is held by institutional investors. This ratio is lower than $65.53 \%$ reported by Chen et al. (2012), indicating that more than half of the ownership of the US sample examined by Chen et al. (2012) was held by institutional investors, while less than a quarter for the Egyptian sample.

\subsection{Regression Results}

Evidence on asymmetric cost behavior

Table 4 exhibits results of running model 1 to examine whether COGS exhibit asymmetric cost behavior. The results indicate that $\mathrm{F}$-value $=765.30(0.000)$ and adj. $\mathrm{R}^{2}=$ 0.84 , implying that the basic model is statistically significant and explains $84 \%$ of COGS variations. Further, the coefficients $\beta 1$ and $\beta 2$ found to be statistically significant at $1 \%$ 
level; $\beta 1$ (1.05) is positive, and $\beta 2(-0.20)$ is negative. These results are consistent with the empirical hypothesis of asymmetric cost behavior proposed by Anderson et al. (2003). Moreover, the value of 1.05 of $\beta 1$ coefficient indicates that COGS increase by $1.05 \%$ when activity increases by $1 \%$. However, the sum of both $(\beta 1+\beta 2)=0.85$, which indicates that COGS decreased by only $0.85 \%$ when activity decreases by $1 \%$. Moreover, Subramaniam and Weidenmier (2003) find that COGS increase by 1.01 , but decrease by 0.94 for a USA sample, and Ibrahim (2015) find that COGS increase by $1.02 \%$, but decrease by $0.57 \%$ for an Egyptian sample.

\section{Insert Table 4 about here}

The regression results of estimating the basic model provide evidence on asymmetric cost behavior from emerging economies. Furthermore, the results are consistent with those of Subramaniam and Weidenmier (2003), Weiss (2010), Balakrishnan et al. (2014), and Ibrahim (2015) who find that COGS behavior is asymmetric. The results assert arguments of the resources-adjustment hypothesis presented by Anderson et al. (2003) and Baumgarten (2012) that the managers' decision regarding the resources adjustments when activity changes is one of the main determinants of cost behavior, and with cost asymmetry theory documented by Banker and Byzalov (2014).

One possible explanation for the sticky behavior of COGS is that managers are regularly induced by discounts of suppliers on large quantities of raw materials. This will result in several slopes and several rates per unit of raw materials, which are the main components of COGS. Horngren et al. (2012) explain the influence of large raw materials discounts on cost behavior and show that several slopes could exist within small ranges, which results in a nonlinear cost curve. Further, the second component of COGS is labor costs; both learning curves and intellectual capital may explain the asymmetric behavior of labor costs. The notion of learning curves explains that in labor-intensive industries, workers become more experienced overtime, which will improve productivity and reduce labor costs. For intellectual capital, managers will not retire intelligent workers and highly skilled employees when activity declines, which increases cost stickiness of COGS.

\section{Board Characteristics and Asymmetric Cost Behavior}

The literature examines the variables affecting cost stickiness once by including them as interaction-terms only, such as Anderson et al. (2003), Subramaniam \& Weidenmier (2003), and Kama \& Weiss (2013), and once by including them as interaction-terms and standalone variables together at the same model, such as Calleja et al. (2006), Chen et al. (2012) and Dierynck et al. (2012). Therefore, I prefer to run the models once without standalone variables and once with standalone variables and before and after the control variables as well. Table (5) shows the results in four columns.

Column (1) of Table 5 exhibits that $\boldsymbol{\beta} 1$ is positive and statistically significant at the $1 \%$ level $(\beta 1=1.09$, $\mathrm{t}$-statistic $=42.20)$, while $\boldsymbol{\beta 2}$ is negative and statistically significant at the $1 \%$ level $(\boldsymbol{\beta 2}=-0.29$, $\mathrm{t}$-statistic $=-8.25)$. Likewise, the coefficients $\beta 1$ are positive and statistically significant at $1 \%$ and the coefficients $\beta 2$ are negative and statistically significant at $1 \%$ even after adding control variables and standalones variables at the other three columns. The results of the four columns are consistent with the empirical hypothesis of cost stickiness, which confirms that COGS behave sticky as found when running the basic model as shown in Table 4. 


\section{Insert Table 5 about here}

For board size variable, the coefficients are negative and statistically significant at $1 \%$ as shown in the four columns of Table $5\{\boldsymbol{\beta 3}=-0.05(-2.89) ;-0.18(-8.90) ;-0.06(-2.69)$; $0.19(-12.04)\}$. Based on a rule set by Anderson et al. (2003) to explain the influence of included variables, the negative and significant coefficient implies that observations with larger boards exhibit greater cost stickiness. This result is consistent with my argument that smaller boards seem to be a good CG mechanism, where smaller boards can reduce the conflict that could arise between members and ease communication within the company. The result is also consistent with the argument of Chen et al. (2012) that larger boards could alleviate governance quality. Further, the result confirms the argument of Jensen (1993) that larger boards may suffer from more difficulty in coordination among board members and argument of Goodstein et al. (1994) that members of the larger boards are less likely to become involved in strategic decisions. Another possible explanation is that small boards are more likely to monitor the decisions of resources adjustment effectively, with fewer disputes and a high degree of concord between board members than larger boards.

For role duality, the results indicate that $\beta 4$ coefficients are negative and statistically significant at $1 \%$ and $5 \%$ as shown in the four columns of Table $5\{\boldsymbol{\beta} 4=-0.58(-13.06)$; $0.17(-1.92) ;-0.60(-11.29) ;-0.19(-2.84)\}$, whether with standalone and control variables or without. This result proves that role duality could influence cost behavior, observations with role duality are more likely to experience greater cost stickiness. This result confirms the agency theory argument that separation of board chairman/CEO roles could increase independence, effective monitoring, and mitigate power concentration, which ultimately will improve managers' decisions. One explanation for this result is that when board chairmen work as CEOs at the same time, this may create a state of power concentration. My explanation is that when activity changes, board chairmen who work as CEOs at the same time may allow managers adjusting the resources in any way regardless of its consequence on cost behavior.

For the ratio of non-executives on boards, the results indicate that the coefficients are negative and statistically significant at the $1 \%$ level for the four cases $\{\boldsymbol{\beta 5}=-1.90$; ($11.01) ;-0.96(-4.46) ;-1.85(-9.14) ;-0.95(-5.81)\}$. This result means that cost stickiness is greater in boards with a higher ratio of non-executives, which contradicts the study third hypothesis. The result disagrees with Crowther and Jatana (2005) and Gul and Leung (2004) who argue that a higher non-executives number on boards is a signal of strong CG system that will motivate the level of effective monitoring and transparency. Moreover, Fama \& Jensen (1983) and agency theory argue that independent directors on boards could mitigate managers' opportunistic actions through effective monitoring, which contradicts the results found. One explanation for this result is that non-executive directors may not have sufficient information and are not engaged in daily operations enough to affect the decisions of resources-adjustments. Therefore, reducing the number of nonexecutives may be preferable for alleviating stickiness behavior. Fuerst and Kang (2004) and Bozec (2005) find similar results. Accordingly, I reject the study hypothesis $\mathrm{H}_{3}$.

For the control variables, Table (5) shows similar results before and after adding the standalone variables. First, the coefficients of Successive Decrease are positive and statistically significant at $1 \%\{\beta 6=0.38$ (3.81); $0.38(4.81)\}$ as shown columns (2) and (4), A positive significant coefficient implies that cost stickiness degree gets lower during a demand-declining period preceded by demand-declining periods. This asserts the 
argument that the successive decrease in sales makes managers recognize that sales decline is permanent, and thus, they take their decision by retiring the slack resources, and thus, costs decrease become similar to costs increase for the equivalent sales change, which decreases cost stickiness. Anderson et al. (2003), Chen et al. (2012), Kama \& Weiss (2013) and Banker et al. (2013) find a positive and statistically significant correlation for the successive decrease variable, consistent with their expectations, while Dierynck et al. (2012) find a statistically insignificant correlation.

Second, the coefficients of Economic Growth show a positive and statistically significant correlation at $1 \%$ before and after including the standalone variables $\{\beta 7=0.10$ (2.77); 0.10 (3.46)\}, which means that during the higher economic growth periods, COGS shows lower cost stickiness. Anderson et al. (2003) and Ibrahim (2015) argue that during the economic growth periods, managers are optimistic and think that any sales decline is temporary, and thus, do not retire the slack resources even if the sales decline, which causes more cost stickiness. However, the regression result comes inconsistent with this argument and with the results find by Anderson et al. (2003), Banker et al. (2013), and Ibrahim (2015) who find a significant negative relation and with Dierynck et al. (2012) who find an insignificant relation.

Finally, the coefficient of Institutional Ownership exhibits a positive and statistically significant correlation at $1 \%\{\beta 8=0.56$ (3.28); $0.57(4.29)\}$, which indicates that firms with higher institutional ownership exhibit lower cost stickiness, which is consistent with the study expectations. This is also consistent with the agency theory and efficient monitoring hypothesis that institutional investors hold experience, analytical skills, and power than individuals that enable them to affect and monitor effectively the managers' decisions (Jensen and Meckling, 1976; Abdel-Fattah, 2008). This result is consistent with Chen et al. (2012) who find that institutional ownership can be an effective governance mechanism that is able to mitigate the influence of agency problem on stickiness of SG\&A costs in a sample of USA firms.

It is noteworthy that the asset intensity was added as a control variable with a positive relation expectation with cost stickiness, however, adding this variable found to increase the Multicollinearity levels with other independent variables to unacceptable levels, so that I excluded it from the models. The bottom of table (5) shows that the Multicollinearity is not a problem, since VIF and condition index values are within the acceptable levels. For example, the maximum VIP is 7.18 lower than 10 (Kennedy 1992; Herrmann et al. 2003; Ibrahim 2015). Moreover, I find the results similar when estimating a fixed-effects model.

Overall, COGS insists to behave sticky and board size, role duality and non-executive are found to increase cost stickiness whether before or after adding the standalone and control variables. Further, successive decrease, economic growth, and institutional ownership are found to decrease cost stickiness.

\subsection{Robust Analysis}

I divide the study's main sample into two sub-samples using the median of each board characteristic. Observations with values greater than or equal median of each board characteristic make up the first sub-sample while observations with values less than median make up the second sub-sample. Next, I run model (1) to examine cost behavior and compare the cost stickiness magnitude in each sub-sample. Table 6 exhibits the results. 
For sub-sample with board size above or equal the median, COGS found to be more sticky $(\boldsymbol{\beta} 1=1.02$, t-statistic $=35.38 ; \boldsymbol{\beta} 2=-0.33$, t-statistic $=-8.07)$ than its counterpart subsample $(\boldsymbol{\beta} 1=1.10, \mathrm{t}$-statistic $=20.12 ; \boldsymbol{\beta} 2=0.15$, $\mathrm{t}$-statistic $=2.78)$. The comparison result indicates that observations with larger boards experience greater cost stickiness, which asserts that results found in Table 5. For sub-sample with role duality, COGS found to be more sticky $(\boldsymbol{\beta 1}=1.10$, t-statistic $=18.05 ; \boldsymbol{\beta 2}=-0.17$, t-statistic $=-2.75)$ than its counterpart sub-sample $(\boldsymbol{\beta 1}=0.89$, t-statistic $=18.65 ; \boldsymbol{\beta 2}=0.19$, t-statistic $=1.78)$, which indicates that separation of chairman and CEO jobs could mitigate magnitude of cost stickiness, which asserts the results found in Table 5.

\section{Insert Table 6 about here}

For sub-sample with non-executives ratio greater than or equal the median, COGS found to be more sticky $(\boldsymbol{\beta} 1=0.95, \mathrm{t}$-statistic $=20.44 ; \boldsymbol{\beta 2}=-0.19$, $\mathrm{t}$-statistic $=-3.90)$, compared with its counterpart sub-sample $(\boldsymbol{\beta 1}=1.12$, t-statistic $=37.19 ; \boldsymbol{\beta 2}=0.16$, $\mathrm{t}$ statistic $=1.74)$, which implies that the higher non-executives on boards the higher the cost stickiness, asserting the results exhibited in Table 5.

The overall conclusion is that COGS behave asymmetrically, not as assumed by the traditional cost model that costs should behave in a linear form with equivalent activity changes. The result confirms the cost asymmetry theory assumed by Banker and Byzalov (2014) and asserts arguments of the resources-adjustment hypothesis presented by Anderson et al. (2003) and Baumgarten (2012). This implies that there is a gap between linear cost assumption and the real cost behavior, which implies that applying any management accounting technique that depends on the linear cost assumption, such as CVP, ABC or earnings forecast could present distorted results and thus lead to misleading decisions.

On the other hand, board characteristics found to affect the cost stickiness extent, which implies that effective CG systems may be a potential solution that could affect the managers' decisions regarding the resources adjustments, and thus, could mitigate the cost stickiness extent. The results also confirm some of agency theory arguments that smaller boards, board/CEO separation, and institutional investors are more likely to provide effective monitoring and controlling for managers' decisions including the resourcesadjustments decisions when the activity changes. Accordingly, these results provide important implications to investors and analysts when conducting earnings forecasts, to management accountants when making cost estimation and allocation, to governance authorities when setting governance codes and regulations and to academic researchers in investigating determinants of cost behavior.

\section{Conclusion}

This study extends the cost stickiness literature by providing new evidence from emerging economies and by investigating the influence of board characteristics as one of CG mechanisms. Results indicate that COGS behavior is sticky; it increases (1.05\%) more than it does decrease $(0.85 \%)$ with a $1 \%$ activity change. Further, board characteristics found to affect the managers' decisions, and thus, cost behavior, where all examined board characteristics found to affect cost stickiness in some way. Results indicate that smaller boards and chairman/CEO separation could mitigate cost stickiness while the ratio of nonexecutives on boards found to increase cost stickiness. Further, the institutional ownership 
as a control variable found to mitigate cost stickiness degree. This supports the study main suggestion that effective corporate governance mechanisms could affect managers' decisions and thus cost behavior. The overall conclusion is that cost stickiness is a prevalent cost behavior in emerging economies as well as in developed ones and that CG could affect managers' decisions regarding resources adjustment when activity changes.

One main implication is that management accountants should estimate the different cost accounting and management accounting techniques, such as standard costing, cost planning, ABC, CVP, and budgeting carefully, since the slope is not always constant, as assumed by the traditional cost model. For CG regulators, they should consider how managers' deliberate intervention could make costs behave asymmetrically, and how CG could mitigate this intervention. They should consider smaller board size, chairman/CEO separation and institutional ownership as variables that could mitigate cost stickiness. For investors and analysts, they should take into consideration the asymmetric cost behavior when conducting earnings forecasts.

This study suffers some limitations. First, the study examines only three board characteristics, although there are several other variables that still need investigation. Second, the study examines the potential impact of CG on COGS, although there are several other costs, such as SG\&A, OC, and TC, which still need investigation. Third, the study samples are deemed small compared with those examined in the developed countries.

Finally, future research can investigate the relationship between asymmetric cost behavior and other CG mechanisms, such as audit committee characteristics, auditor type, and different variables of ownership structures. Moreover, further research is still needed to investigate the relationship between managerial incentives and asymmetric cost behavior. I find paucity in studies that investigate this relationship. Further, future authors should be cautious that either costs or sales figures or both could be manipulated, which could mislead the results of discovering cost stickiness. They should consider this issue and examine real costs and sales figures before any manipulations. Finally, future research can suggest solutions, where I find that most prior studies provide either evidence on the asymmetric cost behavior or a link between this behavior and other accounting issues. 


\section{References}

Abdel-Fattah, T. M. H. (2008). "Voluntary disclosure practices in emerging capital markets: the case of Egypt”. Ph.D. Thesis. Durham University.

Abu-Serdaneh, J. (2014), "The asymmetric behavior of cost: evidence from Jordan", International Business Research, Vol. 7 No. 8, pp. 113: 122.

Ailken, L. S., and West, S. G. (1991), Multiple Regression: testing and interpreting interactions. Newbury Park, CA: Sage Publications.

Anderson, M. C., Banker, R. D., and Janakiraman, S. N. (2003), "Are selling, general, and administrative costs sticky?”, Journal of Accounting Research, Vol. 41 No. 1, pp.47-63.

Balakrishnan, R. E., Labro, E. and Soderstrom, N. S. (2014), "Cost structure and sticky costs”, Journal of Management Accounting Research, Vol. 26, No. 2, pp. 91-116.

Banker, R. D., and Byzalov, D. (2014), "Asymmetric cost behavior", Journal of Management Accounting Research, Vol. 26 No. 2, pp. 43-79.

Banker, R. D., Byzalov, D., and Chen, L. T. (2013), "Employment protection legislation, adjustment costs and cross-country differences in cost behavior", Journal of Accounting and Economics, Vol. 55 No. 1, pp. 111-127.

Baumgarten, D. (2012), "The cost stickiness phenomenon: causes, characteristics, and implications for fundamental analysis and financial analysts' forecasts", Gabler Verlag, Springer Fachmedien Wiesdbadn.

Bozec, R. (2005), "Board of directors, market discipline and firm performance", Journal of Business, Finance, and Accounting, Vol. 32 No. 9-10, pp. 1921-1960.

Brasch, H. (1927).,"Zur Parxis der Unkostenschwankungen und ihrer Erfassung (2) (The practice of cost fluctuation and their measurement)", Betriebswirtschaftliche Rundschau, Vol. 4, pp. 65-73.

Calleja, K., Steliaros, M. and Thomas, D. C. (2006), "A note on cost stickiness: Some international comparison", Management Accounting Research, Vol. 17 No.2, pp. 127-140.

Chen, C. X., Lu, H. and Sougiannis, T. (2012), "The agency problem, corporate governance, and the asymmetric behavior of selling, general, and administrative costs", Contemporary Accounting Research, Vol. 29 No. 1, pp. 252-282.

Cornett, M. M., Marcus, A. J., Saunders, A., and Tehranian, H. (2007), "The impact of institutional ownership on corporate operating performance". Journal of Banking and Finance, Vol. 31, pp. 17711794.

Crowther, D., and Jatana, R. (2005), "Agency theory: a cause of failure in corporate governance", International dimensions of corporate social responsibility, Vol.1, pp. 135-152.

Dalla Via, N. and Perego, P. (2014), "Sticky cost behavior: evidence from small and medium-sized companies", Accounting \& Finance, Vol. 54, No. 3, pp. 753-778.

Dierynck, B., Landsman, W. R., and Renders, A. (2012), "Do managerial incentives drive cost behavior? Evidence about the role of the zero earnings benchmark for labor cost behavior in private Belgian firms", The Accounting Review, Vol. 87 No. 4, pp. 1219-1246.

Fama, E. F., and Jensen, M. C. (1983), "Separation of ownership and control", Journal of Law and Economics, Vol. 26 No. 2, pp. 301: 325.

Forker, J. J. (1992), "Corporate governance and disclosure quality", Accounting and Business Research Journal, Vol. 22 No. 86, pp. 111-124.

Fuerst, O., and Kang, S. H. (2004), "Corporate governance, expected operating performance, and pricing”, Corporate Ownership and Control, Vol. 1 No. 2, pp. 13-30.

Goodstein, J., Gautam, K., and Boeker, W. (1994), "The effects of board size and diversity on strategic changes", Strategic Management Journal, Vol. 15, No.3, pp. 241-250. 
Guenther, T. W., Riehl, A. and Robler, R. (2014), "Cost stickiness: state of the art of research and implications", Journal of Management Control, Vol. 24 No. 4, pp. 301-318.

Gul, F. A., and Leung, S. (2004), "Board leadership, outside directors' expertise and voluntary corporate disclosure", Journal of Accounting and Public Policy, Vol. 23 No. 5, pp. 351-379.

Haniffa, R. M., and Cooke, T. E. (2002), "Culture, corporate governance and disclosure in Malaysian corporations", ABACUS, Vol. 38 No. 3, pp. 317-349.

Haniffa, R. M., and Hudaib, M. (2006), "Corporate governance structure and performance of Malaysian listed companies", Journal of Business Finance and Accounting, Vol. 33 No. 7, pp. 1034-1062.

Helland, E., and Sykuta, M. E. (2005), "Who's monitoring the monitor? Do outside directors protect shareholders' interests?” The Financial Review, Vol. 40, No. 2, pp. 155-172.

Heracleous, L. (2001), "What is the impact of corporate governance on organizational performance?" Corporate Governance: An International Review, Vol. 9 No. 3, pp. 165-173.

Herrmann, D., Tatsuo, I., and Wayne, B. T. (2003), "The sale of assets to manage earnings in Japan". Journal of Accounting Research, Vol. 41 No. 1, pp. 89-108.

Horngren, C. T., Datar, S. M., and Rajan, M. (2012), “Cost Accounting: A Managerial Emphasis”, 14 edition. Upper Saddle River, NJ : Prentice Hall.

Huther, J. (1997), “An empirical test of the effect of board size on firm efficiency”, Economic Letters, Vol. 54 No. 3, pp. 259-264.

Ibrahim, A. E. A. (2015), “The economic growth and cost stickiness: evidence from Egypt", Journal of Financial Reporting and Accounting, Vol. 13, No. 1, pp. 119-140.

Jensen, M. (1993), "The modern industrial revolution, exit and the failure of internal control systems", Journal of Finance, Vol. 48, No. 3, pp. 831-880.

Jensen, M. C., and Meckling, W. H. (1976), "Theory of the firm: Managerial behavior, agency costs and ownership structure", Journal of Financial Economics, Vol. 3 No. 4, pp. 305-360.

John, K. and Senbet, W. (1998), "Corporate governance and board effectiveness", Journal of Banking and Finance, Vol. 22, pp. 371-403.

Kama, I., and Weiss, D. (2013), "Do earnings targets and managerial incentives affect sticky costs?" Journal of Accounting Research, Vol. 51 No. 1, pp. 201-224.

Kelton, A. S., and Yang, Y. (2008), "The impact of corporate governance on internet financial reporting", Journal of Accounting and Public Policy, Vol. 27 No. 1, pp. 62-87.

Kennedy, P. (1992), A guide to econometric methods, MIT Press, Cambridge, MA.

Koo, J-H., Song, S., and Paik, T-Y. (2015), "Earnings management and cost stickiness", Advanced Science and Technology Letter, Vol. 84 (Business 2015), pp. 40-44.

Laing, D. and Weir, C. M. (1999), "Governance structures and corporate performance in the UK firms", Management Decision, Vol. 37 No. 5, pp. 457-464.

Mak, Y., and Roush, M. (2000), "Factors affecting the characteristics of boards of directors: an empirical study of New Zealand initial public offering firms", Journal of Business Research, Vol. 47, pp. 147159.

Mederios, O. R. and De Souza Costa, P. (2004), "Cost stickiness in Brazilian firms", Working paper, Universidad de Brasilia.

Pearce, J. A., and Zahra, S. A. (1992), "Board composition from a strategic contingency perspective", Journal of Management Studies, Vol. 29 No. 4, pp. 411-438.

Pichetkun, N. (2012), "The determinants of sticky cost behavior on political costs, agency costs, and corporate governance perspectives", Ph.D. Thesis, Faculty of Business Administration, Rajamangala University of Technology Thanyaburi, Thailand. 
Porporato, M., and Werbin, E. (2012), "Evidence of sticky costs in banks of Argentina, Brazil, and Canada", International Journal of Financial Services Management, Vol. 5 No. 4, pp. 303-320.

Shehata, N., and Dahawy, K. M. (2013), "2013 Review of the implementation status of corporate governance disclosures: Egypt", Paper presented at the United Nation Conference on Trade and Development, 6-8 November 2013, Palais des Nations, Geneva.

Shleifer, A., and Vishny, R. (1997), "A survey of corporate governance”, The Journal of Finance, Vol. 52 No. 2, pp. 737-83.

Subramaniam, C. and Weidenmier, M. L. (2003), "Additional evidence on the sticky behavior of costs", working paper, Texas Christian University, Texas.

Vafeas, N., and Theodorou, E. (1998), "The relationship between board structure and firm performance in the UK" The British Accounting Review, Vol. 30 No. 4, pp. 383-407.

Weiss, D. (2010), “Cost behavior and analysts' earnings forecasts", The Accounting Review, Vol. 85, No. 4, pp.1441-1474.

Xue, S., and Hong, Y. (2015), "Earnings management, corporate governance and expense stickiness", China Journal of Accounting Research (in press).

Yermack, D. (1996), "Higher market valuation of firms with a small board of directors", Journal of Financial Economics, Vol. 40, No. 2, pp. 185-211. 
Table 1: The Study Samples (2008-2013)

\begin{tabular}{|l|c|c|}
\hline & Basic Sample & CG Sample \\
\hline Starting Samples & 600 & 600 \\
\hline (-) Observations of financial institutions & $(120)$ & $(120)$ \\
\hline (-) Observations with missing data on either costs or net sales & $(25)$ & $(25)$ \\
\hline (-) Observations with costs $>$ net sales & $(23)$ & $(23)$ \\
\hline (-) Outliers & $(6)$ & $(10)$ \\
\hline Final Samples & $\mathbf{4 2 6}$ & $\mathbf{4 2 2}$ \\
\hline
\end{tabular}

The 100 companies of the index (EGX100) represent the initial study sample with 600 observations during a six-year study period (2008-2013). Then, I excluded 20 financial institutions with 120 firm-year observation.

Table 2: The Variables' Definitions and Measurements

\begin{tabular}{|c|c|c|c|}
\hline Variable & Definition & Measurement & Source \\
\hline \multicolumn{4}{|c|}{ Dependent Variable: } \\
\hline$\Delta \mathrm{COGS}_{\mathrm{it}}$ & $\begin{array}{l}\text { Change of Cost } \\
\text { of Goods Sold }\end{array}$ & $\begin{array}{l}\text { It is measured as the COGS of year } t \text { divided } \\
\text { by that of year } t-1 \text { for the firm } \mathrm{i} \text {. }\end{array}$ & Annual Report \\
\hline \multicolumn{4}{|c|}{ Independent Variables: } \\
\hline$\Delta$ Sales $_{\text {it }}$ & Change of Sales & $\begin{array}{l}\text { It is measured as the net sales of year } t \text { divided } \\
\text { by the net sales of year } t-1 \text { for the firm } i \text {. }\end{array}$ & Annual Report \\
\hline DecDummy $_{\text {it }}$ & $\begin{array}{l}\text { Dummy } \\
\text { Variable }\end{array}$ & $\begin{array}{l}\text { A dummy variable that equals } 1 \text { if the current } \\
\text { year's net sales are less than the previous } \\
\text { year's net sales and } 0 \text { otherwise. }\end{array}$ & $\begin{array}{l}\text { Created based on } \\
\text { data from annual } \\
\text { report }\end{array}$ \\
\hline $\begin{array}{l}\operatorname{DecDummy}_{\text {it }} \\
\times \log \left(\Delta \text { Sales }_{\text {it }}\right)\end{array}$ & $\begin{array}{l}\text { Interaction- } \\
\text { Term }\end{array}$ & $\begin{array}{l}\text { A two-way interaction term that results from } \\
\text { multiplying the dummy variable by the natural } \\
\text { logarithm of changes in net sales for the year } t \\
\text { and firm i. }\end{array}$ & $\begin{array}{l}\text { Created based on } \\
\text { data from annual } \\
\text { report }\end{array}$ \\
\hline \multicolumn{4}{|c|}{ Corporate Governance Variables: } \\
\hline Board size $_{\text {it }}$ & Size of Board & $\begin{array}{l}\text { The total number of directors on the board of } \\
\text { firm i during the year } t \text {. }\end{array}$ & Disclosure Book \\
\hline Role duality it & $\begin{array}{l}\text { Board Chairman } \\
\text { Role Duality }\end{array}$ & $\begin{array}{l}\text { A dummy variable takes the value } 1 \text { if the } \\
\text { board chairman and CEO are the same person } \\
\text { and } 0 \text { otherwise. }\end{array}$ & Disclosure Book \\
\hline $\begin{array}{l}\text { Non-executives } \\
\text { ratio it }^{\text {it }}\end{array}$ & Non-executives & $\begin{array}{l}\text { The ratio of the number of non-executive } \\
\text { directors on the board to the total number of } \\
\text { board directors of firm i during the year t. }\end{array}$ & Disclosure Book \\
\hline \multicolumn{4}{|l|}{ Control Variables: } \\
\hline $\begin{array}{l}\text { Successive } \\
\text { Decrease }_{\text {it }}\end{array}$ & $\begin{array}{l}\text { Dummy } \\
\text { Variable }\end{array}$ & $\begin{array}{l}\text { An indicator variable that takes the value } 1 \text { if } \\
\text { the net sales of the year } t-1 \text { are lower than the } \\
\text { net sales of the year } t-2 \text {, and zero otherwise. }\end{array}$ & $\begin{array}{l}\text { Created based on } \\
\text { data from annual } \\
\text { report }\end{array}$ \\
\hline Economic Growth $_{\text {it }}$ & Real GDP & $\begin{array}{l}\text { The percentage growth in real gross domestic } \\
\text { product during the year t, which is used as a } \\
\text { proxy for economic growth. It was obtained } \\
\text { from the website of International Monetary } \\
\text { Fund. }\end{array}$ & $\begin{array}{l}\text { International } \\
\text { Monetary Fund } \\
\text { Website. }\end{array}$ \\
\hline $\begin{array}{l}\text { Institutional } \\
\text { Ownership }_{\text {it }}\end{array}$ & $\begin{array}{l}\text { Ownership of } \\
\text { Institutional } \\
\text { investors }\end{array}$ & $\begin{array}{l}\text { The total number of shares held by } \\
\text { institutional investors divided by the total } \\
\text { number of outstanding shares of firm } \mathrm{i} \text { during } \\
\text { the year t. }\end{array}$ & Disclosure Book \\
\hline
\end{tabular}


Table 3: Descriptive Statistics*

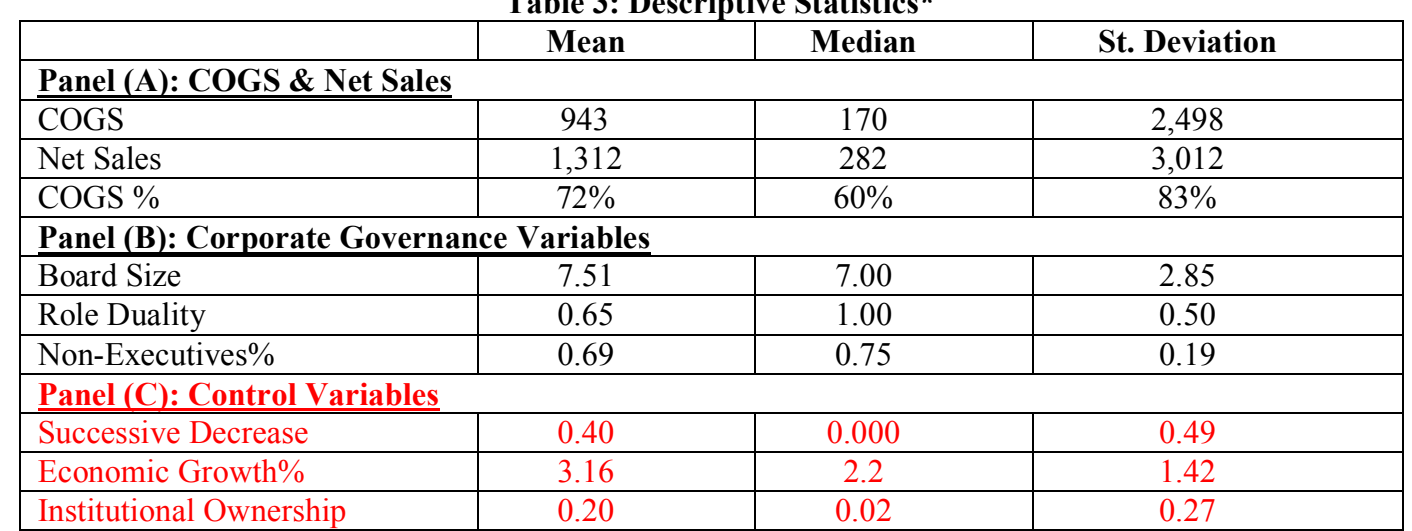

*The reported numbers are in millions of Egyptian pounds. The results presented in table exclude observations with costs exceeding revenues for the current year, but do not exclude outliers.

Table 4: Results Running Model 1

\begin{tabular}{|l|c|c|c|c|c|c|c|c|c|}
\hline & Con. & $\boldsymbol{\beta 1}$ & $\boldsymbol{\beta 2}$ & $\boldsymbol{\beta 1}+\boldsymbol{\beta 2}$ & $\mathbf{A d j .} \mathbf{R}^{2}$ & $\mathbf{F - v a l u e}$ & $\begin{array}{c}\text { Condition } \\
\text { Index* }\end{array}$ & VIF* $^{*}$ & $\begin{array}{c}\text { Year } \\
\text { Dummies }\end{array}$ \\
\hline $\begin{array}{l}\text { COGS } \\
\text { Model }\end{array}$ & $\begin{array}{c}-0.04 \\
(-0.98)\end{array}$ & $\begin{array}{c}1.05 * * * \\
(33.79)\end{array}$ & $\begin{array}{c}-0.20^{* * *} \\
(-2.86)\end{array}$ & 0.85 & 0.84 & $\begin{array}{c}765.3 \\
0\end{array}$ & 2.14 & 2.06 & Suppressed \\
\hline
\end{tabular}

*Condition Indexes are less than five and VIF values are less than three, which indicate the non-existence of Multicollinearity problem (Kennedy, 1992; Herrmann et al., 2003). T-values are in parentheses. 
Table 5: Regression Results of Models 2 \& 3

\begin{tabular}{|c|c|c|c|c|}
\hline \multirow[b]{2}{*}{$\underline{\text { Variables Statistics }}$} & \multicolumn{2}{|c|}{ No Standalone } & \multicolumn{2}{|c|}{ Standalone } \\
\hline & $\begin{array}{c}\text { Before } \\
\text { Controls } \\
(1) \\
\end{array}$ & $\begin{array}{c}\text { After } \\
\text { Controls } \\
(2) \\
\end{array}$ & $\begin{array}{c}\text { Before } \\
\text { Controls } \\
(3) \\
\end{array}$ & $\begin{array}{c}\text { After } \\
\text { Controls } \\
(4) \\
\end{array}$ \\
\hline 及0: Intercept & $\begin{array}{l}-0.03^{* *} \\
(-2.14)\end{array}$ & $\begin{array}{c}-0.02 \\
(-1.20)\end{array}$ & $\begin{array}{c}-0.01 * * * \\
(-2.90)\end{array}$ & $\begin{array}{c}0.10 \\
(1.60)\end{array}$ \\
\hline 及1: $\log (\Delta$ Sales $)$ & $\begin{array}{l}1.09 * * * \\
(42.20)\end{array}$ & $\begin{array}{l}1.13 * * * \\
(39.33)\end{array}$ & $\begin{array}{l}1.11 * * * \\
(45.87)\end{array}$ & $\begin{array}{l}1.07 * * * \\
(42.75)\end{array}$ \\
\hline 及2: DecDummy $\times \log (\Delta$ Sales $)$ & $\begin{array}{c}-0.29 * * * \\
(-8.25)\end{array}$ & $\begin{array}{c}-0.26 * * * \\
(-4.27)\end{array}$ & $\begin{array}{c}-0.31 * * * \\
(-9.85)\end{array}$ & $\begin{array}{c}-0.19 * * * \\
(-3.84)\end{array}$ \\
\hline \multicolumn{5}{|l|}{$\begin{array}{l}\text { Three-way Interaction Terms (DecDummy } \times \log \Delta \text { Sales } \\
\times \text { Variable) }\end{array}$} \\
\hline B3: DecDummy $\times \log (\Delta$ Sales $) \times$ Board Size & $\begin{array}{c}-0.05 * * * \\
(-2.89)\end{array}$ & $\begin{array}{c}-0.18 * * * \\
(-8.90)\end{array}$ & $\begin{array}{c}-0.06 * * * \\
(-2.69)\end{array}$ & $\begin{array}{c}-0.19 * * * \\
(-12.04)\end{array}$ \\
\hline 及4: DecDummy $\times \log (\Delta$ Sales $) \times$ Role Duality & $\begin{array}{r}-0.58 * * * \\
(-13.06)\end{array}$ & $\begin{array}{l}-0.17 * * \\
(-1.92)\end{array}$ & $\begin{array}{l}-0.60 * * * \\
(-11.29)\end{array}$ & $\begin{array}{c}-0.19 * * * \\
(-2.84)\end{array}$ \\
\hline B5: DecDummy $\times \log (\Delta$ Sales $) \times$ Non-executives & $\begin{array}{r}-1.90 * * * \\
(-11.01)\end{array}$ & $\begin{array}{c}-0.96 * * * \\
(-4.46)\end{array}$ & $\begin{array}{c}-1.85 * * * \\
(-9.14)\end{array}$ & $\begin{array}{c}-0.95 * * * \\
(-5.81)\end{array}$ \\
\hline 及6: DecDummy $\times \log (\Delta$ Sales $) \times$ Successive Decrease & --- & $\begin{array}{c}0.38 * * * \\
(3.81)\end{array}$ & --- & $\begin{array}{c}0.38 * * * \\
(4.81)\end{array}$ \\
\hline 及7: DecDummy $\times \log (\Delta$ Sales $) \times$ Economic Growth & --- & $\begin{array}{l}0.10 * * * \\
(2.77)\end{array}$ & --- & $\begin{array}{c}0.10 * * * \\
(3.46)\end{array}$ \\
\hline ק8: DecDummy $\times \log (\Delta$ Sales $) \times$ Institutional Ownership & --- & $\begin{array}{c}0.56 * * * \\
(3.28)\end{array}$ & --- & $\begin{array}{c}0.57 * * * \\
(4.29)\end{array}$ \\
\hline \multicolumn{5}{|l|}{ Standalone Variables (Variables without interaction) } \\
\hline$\beta 9$ : Board size & --- & --- & $\begin{array}{c}0.000 \\
(-0.54)\end{array}$ & $\begin{array}{l}-0.01 * \\
(-1.76)\end{array}$ \\
\hline$\beta 10$ : Role Duality & --- & --- & $\begin{array}{l}-0.05^{*} \\
(-1.80)\end{array}$ & $\begin{array}{c}-0.04 \\
(-1.78)\end{array}$ \\
\hline$\beta 11$ : Non-executives $\%$ & --- & --- & $\begin{array}{c}-0.20 * * \\
(-2.31)\end{array}$ & $\begin{array}{c}-0.06 \\
(-0.76)\end{array}$ \\
\hline$\beta 12$ : Successive Decrease & & --- & --- & $\begin{array}{c}0.02 \\
(0.57) \\
\end{array}$ \\
\hline$\beta 13$ : Economic Growth\% & & --- & --- & $\begin{array}{c}0.01 \\
(0.09) \\
\end{array}$ \\
\hline$\beta 14$ : Institutional Ownership & & --- & --- & $\begin{array}{c}0.03 \\
(0.60)\end{array}$ \\
\hline Year Dummies & \multicolumn{4}{|c|}{ Suppressed } \\
\hline F-value (Sig.) & $\begin{array}{l}963.50 \\
(0.000)\end{array}$ & $\begin{array}{l}454.88 \\
(0.000)\end{array}$ & $\begin{array}{l}599.52 \\
(0.000)\end{array}$ & $\begin{array}{l}400.93 \\
(0.000)\end{array}$ \\
\hline VIF (Max) & 3.21 & 6.19 & 2.89 & 7.18 \\
\hline Condition Index & 3.64 & 6.85 & 10.85 & 15.97 \\
\hline Adj.R ${ }^{2}$ & 0.93 & 0.90 & 0.90 & 0.93 \\
\hline $\mathrm{N}$ & 422 & 422 & 422 & 422 \\
\hline
\end{tabular}

$*, * *$, and $* * *$ stand for significance at $10 \%, 5 \%$, and $1 \%$, respectively. T-values are in parentheses. 
Table 6: Results of Robust Regression Analysis

\begin{tabular}{|c|c|c|c|c|c|c|}
\hline & \multicolumn{2}{|c|}{ Board Size } & \multicolumn{2}{|c|}{ Role Duality } & \multicolumn{2}{|c|}{ Non-Executives } \\
\hline & $>=$ Median & $<$ Median & Role Duality & Non-Role Duality & $>=$ Median & $<$ Median \\
\hline Con. & $\begin{array}{c}-0.04 * * \\
(-2.25)\end{array}$ & $\begin{array}{c}-0.01 \\
(-0.27)\end{array}$ & $\begin{array}{c}-0.02 \\
(-0.45)\end{array}$ & $\begin{array}{c}0.02 \\
(0.10)\end{array}$ & $\begin{array}{l}-0.002 \\
(-0.10)\end{array}$ & $\begin{array}{l}-0.03 \\
(-1.22)\end{array}$ \\
\hline$\beta 1$ & $\begin{array}{l}1.02 * * * \\
(35.38)\end{array}$ & $\begin{array}{l}1.10 * * * \\
(20.12)\end{array}$ & $\begin{array}{l}1.10^{* * * *} \\
(18.05)\end{array}$ & $\begin{array}{l}0.89 * * * \\
(18.65)\end{array}$ & $\begin{array}{l}0.95 * * * \\
(20.44)\end{array}$ & $\begin{array}{l}1.12 * * * \\
(37.19)\end{array}$ \\
\hline$\beta 2$ & $\begin{array}{c}-0.33 * * * \\
(-8.07)\end{array}$ & $\begin{array}{c}0.15^{* * *} \\
(2.78)\end{array}$ & $\begin{array}{r}-0.17 * * \\
(-2.75)\end{array}$ & $\begin{array}{l}0.19^{*} \\
(1.78)\end{array}$ & $\begin{array}{c}-0.19 * * * \\
(-3.90)\end{array}$ & $\begin{array}{l}0.16^{*} \\
(1.74)\end{array}$ \\
\hline F-value & $\begin{array}{c}1,320 \\
(0.000)\end{array}$ & $\begin{array}{l}754,28 \\
(0.000)\end{array}$ & $\begin{array}{l}280,65 \\
(0.000)\end{array}$ & $\begin{array}{l}356,50 \\
(0.000)\end{array}$ & $\begin{array}{l}798,25 \\
(0.000)\end{array}$ & $\begin{array}{c}1,244 \\
(0.000)\end{array}$ \\
\hline Adi. R2 & 0.88 & 0.90 & 0.75 & 0.83 & 0.87 & 0.90 \\
\hline
\end{tabular}

$*, * *$, and $* * *$ stand for significance at $10 \%, 5 \%$, and $1 \%$, respectively. T-values are in parentheses.

16

17

18

19

20

21

22

23

24

25

26

27

28

29

30

31

32

33

34

35

36

37

38

39

40

41

42

43

44

45

46

47

48

49

50

51

52

53

54

55

56

57

58

59

60 